\title{
Implementasi Program Pembinaan Kesehatan Perilaku Hidup Bersih dan Sehat Institusi Pendidikan oleh Petugas Promosi Kesehatan Puskesmas Wilayah Kota Surabaya
}

\author{
Hadina Eka Camalia*, Bagoes Widjanarko**, Cahya Tri Purnami** \\ * Yayasan Karunia Abadi Surabaya \\ **Fakultas Kesehatan Masyarakat, Universitas Diponegoro \\ Email:deenacamalea@gmail.com
}

\begin{abstract}
Since 2013 Surabaya has made efforts to increase PHBS of educational institution through "Eco School" and 84\% got coached about PHBS, but not yet able to change student behavior, while in West Surabaya area only 68,75\%. The purpose of this research was to analyze the implementation of health education program of clean and healthy life of educational institution by health promotion officer of public health center Area of West Surabaya City.
\end{abstract}

This was qualitative research. As main informant (health promotion team from 4 public health center) and triangulation informants (4 heads of Puskesmas, 8 teachers of UKS, and 1 kasie of basic health service of Surabaya City Health Office). Determination of informants based on PHBS development guidance. Data analysed with content analysis.

The result showed that PHBS program implementer is not in accordance with Ministerial Decree no 585/menkes/sk/V/2007, all officers have not received PHBS training of educational institution. Funding to achieve healthy schools in public health center taken from $B O K$ and APBD was sufficient. Equipment means for some extension was damaged. Planning conducted once a year discussing the results of observations in educational institutions, especially targets that have not been achieved. Planning, organizing, mobilizing, conducting and appraisal are conducted by promotion team. Indicators of PHBS program that have not reached the target were the availability of healthy canteen and body weighting and measuring height every 6 months.

School PHBS programs have been implemented but the education background of officers has not been appropriate, there were no guidelines and technical guidance specifically for program implementers in public health center.

Keywords: health education, public health center, PHBS

\section{PENDAHULUAN}

Masalah kesehatan pada anak usia sekolah di Indonesia sering berkaitan dengan Perilaku Hidup Bersih dan Sehat (PHBS). Banyak penyakit akibat kurangnya kebersihan lingkungan menyerang anak usia sekolah sehingga dapat menghalangi anak usia sekolah dalam mengembangkan potensi yang dimilikinya. ${ }^{1}$

Perilaku Hidup Bersih dan Sehat (PHBS) anak usia sekolah merujuk pada PHBS institusi pendidikan didalamnya terdapat 8 Indikator keberhasilan PHBS institusi pendidikan yaitu (1) Mencuci 
tangan menggunakan air mengalir dan sabun, (2) Mengkonsumsi jajanan sehat di kantin sekolah, (3) Menggunakan jamban yang bersih dan sehat, (4) Olah raga yang teratur dan terukur, (5) Memberantas jentik nyamuk di lingkungan sekolah, (6) Tidak merokok di sekolah, (7) Menimbang berat badan dan mengukur tinggi badan setiap 6 bulan, (8) Membuang sampah pada tempatnya. ${ }^{2,3}$ Pemerintah berupaya melakukan pembinaan program PHBS institusi pendidikan, pada tahun 2013 institusi pendidikan yang sudah dibina baru mencapai $67,52 \%$ dari target $70 \%$ yang tercantum pada Renstra kementerian kesehatan tahun 2010-2014. ${ }^{4}$

Petugas kesehatan Puskesmas bertugas memberikan pembinaan kepada institusi pendidikan. Sebagai upaya memberikan pengalaman belajar atau menciptakan suatu kondisi bagi perorangan, keluarga, kelompok, dan masyarakat dengan membuka jalur komunikasi, memberikan informasi dan melakukan pendidikan kesehatan untuk meningkatkan pengetahuan, sikap dan perilaku guna membantu masyarakat mengenali dan mengatasi masalahnya sendiri, sehingga sadar, mau dan mampu mempraktekkan PHBS melalui pendekatan pimpinan (advokasi), bina suasana (social support) dan pemberdayaan masyarakat (empowerment). ${ }^{1}$

Adanya permasalahan tersebut menuntut pemerintah untuk menetapkan Kebijakan Nasional Promosi Kesehatan sesuai dengan Surat Keputusan Menteri Kesehatan Nomor 1193/ Menkes/ SK/ X/ 2004. Kebijakan dimaksud juga didukung oleh Surat Keputusan Menteri Kesehatan Nomor 1114/Menkes/SK/VII/2005 tentang Pedoman Pelaksanaan Promosi Kesehatan di Daerah. Pada tahun 2011 diterbitkannya Permenkes RI Nomor 2269/ MENKES/ PER/XI/2011 tentang Pedoman Pembinaan Perilaku Hidup Bersih dan Sehat (PHBS) yang didalamnya terdapat 8 indikator keberhasilan PHBS institusi pendidikan. ${ }^{1}$
Penelitian ini menggunakan metode penelitian kualitatif melalui observasi dan wawancara mendalam (indepth interview) untuk memberikan gambaran tentang efektivitas program pendidikan kesehatan PHBS institusi pendidikan di Wilayah Kota Surabaya. Informan penelitian dibagi menjadi informan utama (tim promosi kesehatan dari 4 Puskesmas) dan informan triangulasi (4 kepala Puskesmas, 8 guru UKS, dan 1 kasie pelayanan kesehatan dasar Dinas Kesehatan Kota Surabaya). Teknik analisis data dengan analisis isi.

\section{HASIL DAN PEMBAHASAN Sumber Daya Manusia}

Mengenai peran dan keterlibatan petugas pelaksana program pendidikan kesehatan PHBS institusi pendidikan berdasarkan latar belakang pendidikan, tupoksi, jumlah tenaga, dan komitmen petugas dalam pelaksanaan program pendidikan kesehatan perilaku hidup bersih dan sehat institusi pendidikan diperoleh informasi yang sama yaitu bahwa kegiatan sebenarnya dilakukan oleh tenaga promosi kesehatan, namun belum adanya tenaga tersebut, maka pengelola program dilaksanakan oleh tenaga kesehatan masyarakat, perawat maupun tenaga kesehatan lingkungan. Hal ini dapat diketahui melalui jawaban informan:

"Saya S1 Kesehatan masyarakat, Ada SK penugasan saya sebagai koordinator promosi kesehatan dari Puskesmas" (IU.1)

"Hendaknya memang dilakukan oleh koordinator yang mempunyai kapasitas di bidang promosi kesehatan, minimal D3 Promkes, tapi kalo tidak ada ya tidak masalah. Karena semua petugas memang harus punya kemampuan mempromosikan kesehatan" (ITKP-3)

"Petugas promkes di puskesmas ini lulusan D3 kesling, tetapi diberi tugas sebagai petugas promkes" (ITKP-4) 
Petugas mempunyai latar belakang bukan dari promosi kesehatan namun petugas dapat diberikan jabatan fungsional sebagai petugas promosi kesehatan dan petugas belum mendapatkan pelatihan tentang program PHBS institusi pendidikan. Hal ini dapat menjadi salah satu penyebab tidak optimalnya implementasi program. Kesesuaian kompetensi dan latar belakang SDM mempengaruhi keberhasilan pelaksanaan program. $^{5}$

Terkait dengan pelatihan PHBS institusi pendidikan pelaksana program pendidikan kesehatan perilaku hidup bersih dan sehat institusi pendidikan dilaksanakan oleh petugas yang belum mengikuti pelatihan PHBS, diketahui melalui jawaban informan sebagai berikut :

"Kalau pelatihan khusus PHBS tidak ada, tetapi yang masih berhubungan misalnya cara pembuatan media, brosur, metode penyuluhan" (IU)

"Pelatihan khusus program PHBS tidak ada, tapi kalo pelatihan tentang UKS didalamnya ada pelatihan PHBS, pola hidup dan sebagainya. Kerjasamanya dengan dinas pendidikan" (IT)

Kaitanya dengan tugas pokok dan fungsi peran petugas, petugas memahami dengan pekerjaanya hanya saja waktunya yang terbatas untuk membagi tugas tersebut, namun informan utama lainnya mengatakan bahwa mereka memahami pekerjaan, didapatkan dari jawaban informan berikut:

"Ya tahu mbak, tentang indikator PHBS sekolah, sasaran, kegiatannya ke sekolah, persyaratan sekolah sehat, dan lain-lain, kami juga bekerjasama dengan guru UKS untuk memantau PHBS sekolah berdasarkan daftar tilik dari kami" (IU)

"Pengetahuan dan kemampuan petugas sudah baik sekali, tapi ya memang di perlukan pelatihan khusus atau pun juklak atau juknis yang sifatnya lebih

\section{Pembiayaan}

Dana untuk program UKS di puskesmas yaitu menggunakan dana APBD/BAU dan BOK (Bantuan Operasional Kesehatan) pada saat turun ke lapangan dana tersebut dialokasikan kepada pelaksana program UKS di puskesmas kemudian dana tersebut digunakan untuk kegiatan-kegiatan program UKS di puskesmas antara lain penyuluhan, pemeriksaan kesehatan, pengobatan dan imunisasi, serta pendidikan kesehatan. Hal ini dapat diketahui melalui jawaban informan:

"Ada dana dari APBD, kalo BOK sekarang tidak bisa jadi tansport petugas, yang dikasih uang transport adalah kader- kader yang membantu" (IU)

"Ada dari BOK dan APBD mbak, itu untuk semua kegiatan program UKS dan penyuluhan termasuk PHBS di sekolah, atau membuat leaflet, media, beli tong sampah dan sebagainya." (IT)

"di sekolah kami di beri dana buat P3K, termasuk obat-obatan, ukuran tinggi dan berat badan, pokoknya kebutuhan UKS dari keuangan BP3, dari puskesmas ada bantuan berupa leaflet, poster, lembar balik, banyak kok." (IT)

Informan utama yang mengatakan bahwa tidak mengetahui jumlah dana, namun ketika petugas membutuhkan untuk memperbanyak leaflet, membuat media, atau kebutuhan penyuluhan lainnya selalu tersedia, ada juga yang mengetahui jumlah dan sumber dana/ anggaran tersebut. 
"Besaran pastinya saya tidak tahu, tetapi saat saya butuh memperbanyak leaflet, membuat media, atau kebutuhan penyuluhan lainya biasanya selalu tersedia" (IU).

"Dana berasal dari APBD/ DAU, dana itu di turun ke puskesmas dan dialokasikan oleh puskesmas ke bagian-bagian puskesmas salah satunya promosi kesehatan, dari situ masuk ke program UKS hingga ke pelaksanaan kegiatan penyuluhan pendidikan kesehatan PHBS institusi pendidikan dan sebagainya" (IT)

mromrast aan reantel, teran tersedra, sedangkan kendaraan yang digunakan untuk bertugas ke lapangan adalah kendaraan dinas dan kendaraan pribadi semuanya cukup.

"Tersedia, ada yang rusak dan beberapa yang harus di upgrade, Kendalanya, Ya kalau DVD materinya rusak itu yang susah, tapi sekarang bisa diakali, anakanak di suruh buka internet, sesuai arahan kita" (IU)

"Kalau ada petugas kunjungan, sebelumnya kami bersih-bersih sekolah, setiap hari juga sekolah dibersihkan sama Pak Bon, halaman, tempat sampah, kamar mandi, semuanya, kami siapkan administrasi UKS aja, kalo untuk perlengkapan kayak brosur, lembar balik, ceklist, atau materi penyuluhan dari pihak puskesmas sendiri, kalau penyuluhan bisa pake aula atau mushola, kalo computer atau leptop biasanya dari puskesmas bawa sendiri, proyektor kami punya, bisa dipake juga, screennya pake dinding." (IT)

Ketersediaan sarana prasaran mempengaruhi keberhasilan program PHBS di sekolah. Penelitian di sekolah dasar di Kabupaten Pati menunjukkan bahwa terdapat hubungan yang signifikan antara ketersediaan fasilitas dengan penerapa PHBS khususnya terkait perilaku membuang sampah pada tempatnya. ${ }^{6}$

\section{Metode}

Dalam hal ini metode merupakan pedoman yang digunakan adalah Kepmenkes No. 1114 tahun 2005 dan Permenkes nomor: 2269 / menkes / per / XI / 2011 tentang pedoman pembinaan perilaku hidup bersih dan sehat. Berdasarkan wawancara mendalam dengan seluruh informan utama didapatkan jawaban yang sama.

"Ada pedoman Standar Kepmenkes 1114 tahun 2005, kalau yang paling baru Pedoman Permenkes Nomor : 2269/Menkes/Per/XI/2011, Kami langsung turun ke lapangan bersama dengan tim, survey, jika ada kendala kami adakan penyuluhan, SOP Ada, kami buat bersama tim, Juklak dan juknis tidak ada, yang ada hanya pedoman, itu pun tidak khusus, tapi sebagai pedoman semua tatanan PHBS dan daftar tilik dari DKK" (IU)

"kalo untuk ke instansi-instansi ada pedoman yang digunakan yaitu Kepmenkes 1114 tahun 2005, kalau yang paling baru Pedoman Permenkes Nomor : 2269/Menkes/Per/XI/2011, SOP Ada dibuat sendiri oleh tim pelaksana, Juklak dan juknis nya ya di pedoman itu, tapi memang masih garis besarnya, untuk yang khusus tatanan instansi-instansi belum ada." (IT)

Untuk mendukung pelaksanaan teknis di sekolah, masih dibutuhkan petunjuk teknis yang khusus untuk lingkungan sekolah. Karena pedoman yang ada masih bersifat umum.

\section{Perencanaan}

Perencanaan meliputi proses pembuatan perencanaan, siapakah yang terlibat dalam membuat perencanaan, waktu pembuatan perencanaan, serta 
kendala yang timbul. didapatkan informasi bahwa proses perencanaan dilakukan setiap tahun oleh tim promosi kesehatan, dalam bentuk rapat koordinasi tujuannya mencapai target yang belum tercapai pada tahun sebelumnya, membahas rencana kegiatan, dan tentang sekolah yang belum tercapai menjadi sekolah sehat.

"Rapat koordinasinya akhir tahun, untuk membahas kegiatan apa saja yang mau dilakukan, misalnya tentang kesehatan gigi diadakan sikat gigi bersama, edukasi pemberantasan jentik nyamuk dan lain- lain" (IU)

"Untuk perencanaan tindakan di masing- masing instansi saya serahkan pada tim promkes, karena yang identifikasi kebutuhan tiap instansi adalah mereka, kegiatan dan kebutuhan serta capaiannya kan berbeda-beda" (IT)

\section{Pengorganisasian}

Dalam implementasi pendidikan kesehatan PHBS institusi pendidikan adalah dengan cara pembentukan tim yang melibatkan petugas puskesmas lain seperti dokter, dokter gigi, bidan, perawat, sanitasi serta kesehatan lingkungan dan lain-lain. Sesampainya di institusi pendidikan yang dituju petugas lalu melaksanakan tupoksi sesuai kewenangannya masing-masing. Ada yang melakukan penyuluhan, pemeriksaan kesehatan, pemeriksaan jamban, sampah, serta kelengkapan 8 indikator PHBS institusi pendidikan.

\footnotetext{
“Awalnya kami tunjuk 1 orang sebagai koordinator program, lalu kami rapat intern untuk yang dipimpin kepala puskesmas untuk membentuk tim promosi kesehatan. Akhirnya disepakati bahwa setiap bagian di puskesmas bisa menjadi tim promkes, tapi tidak semua orang berangkat bu.... Yang memiliki waktu lebih longgarlah yang berangkat." (IT)
}

Untuk keberhasilan program, dibutuhkan keterlibatan pihak lintas sektor yang dapat membantu guru di sekolah dalam melakukan edukasi PHBS. Penelitian menunjukkan bahwa dalam mengambangkan upaya kesehatan di sekolah yang berkesinambungan, dibutuhkan dukungan dari stakeholder yang berkepentingan. ${ }^{7}$

\section{Pelaksanaan}

Dalam implementasi pendidikan kesehatan PHBS institusi pendidikan meliputi bentuk kegiatan yang dilaksanakan dalam program pendidikan kesehatan PHBS institusi pendidikan.

"Kegiatan penyuluhan tentang
kebersihan lingkungan, sikat gigi
bersama, penyuluhan tentang jajanan
berbahaya, sama kalau di SMP atau
SMA tentang reproduksi remaja, juga
ada kegiatan posbindu, Penyuluhan
kebersihan lingkungan, penyakit
menular dan cara pencegahanya, cuci
tangan, bahaya rokok" (IU)

\section{Penilaian}

Hasil pengamatan dan observasi yang dilakukan pada institusi pendidikan menggunakan daftar tilik (lembar checklist) bahwa Institusi pendidikan diwilayah Surabaya Barat yang memenuhi indikator PHBS istitusi pendidikan yaitu memiliki fasilitas : 1) mencuci tangan menggunakan air mengalir dan sabun sebesar $100 \%$, 2) memiliki jajanan sehat di kantin sehat sekolah sebesar $62,5 \%, 3$ ) menggunakan jamban bersih dan sehat sebesar 100\%, 4) olahraga teratur dan terukur sebesar $100 \%$, 5) memberantas jentik nyamuk dilingkungan sekolah sebesar $87,5 \%, 6)$ tidak merokok di sekolah sebesar 100\%, 7) menimbang berat badan dan mengukur tinggi badan setiap 6 bulan sebesar $37,5 \%$, 
8) membuang sampah pada tempatnya sebesar $100 \%$. "kalau untuk kantin sehat kami sudah berupaya agar para pedagang mengikuti saran petugas puskesmas yang pernah datang ke sini memberi penyuluhan, sudah mulai tertib kok mbak, makanan ditutupi, tidak menggunakan saus-saus yang warnanya terlalu pekat, menggunakan air bersih dan sebagainya. Timbang badan dan ukur tinggi badan memang jarang kami lakukan, padahal di juknis penjaringan ada ya... tapi kami tidak pernah menjadwalkan itu, selama ini pelayanan kami untuk anak yang sakit, kami beri obat, dia istirahat di sini, seperti itu" (IT)

Dari 8 indikator PHBS institusi pendidikan tersebut, dapat disimpulkan bahwa indikator yang belum memenuhi target pencapaian adalah memiliki jajanan sehat di kantin sehat sekolah sebesar $62,5 \%$ serta melakukan timbang berat badan dan mengukur tinggi badan setiap 6 bulan yang hanya tercapai $37,5 \%$ dari target capaian minimal $65 \%$. Hal ini dapat disebabkan oleh kurangnya kesadaran akan pentingnya kantin sehat yang bertujuan menyediakan makanan yang aman dan bergizi, menyediakan fasilitas untuk menerapkan ilmu kesehatan dan gizi, dan menerapkan perilaku hidup bersih dan sehat.

Mengkonsumsi makanan sehat merupakan suatu keharusan, terutama bagi anak usia sekolah yang berada dalam tahap pertumbuhan tinggi badan dan berat badan. Pertumbuhan dan dan perkembangan anak di usia sekolah sangatlah pesat, sehingga diperlukan pencatatan pertumbuhan dan perkembangan tubuh secara rutin. Dengan mengetahui berat badan dan tinggi badan seseorang maka akan dapat diperkirakan tingkat kesehatan atau gizinya. Berat badan dan tinggi badan dianjurkan untuk mengukur keadaan gizi karena mudah dilihat, memberikan gambaran keadaan gizi pada saat sekarang dan bila dilakukan secara periodik yaitu minimal 6 bulan sekali pada anak-anak akan dapat memberikan gambaran yang baik tentang pertumbuhan anak, ketelitian pengukuran tidak dipengaruhi oleh keterampilan pengukur dan alat ukur mudah diperoleh.

\section{KESIMPULAN}

SDM untuk Pendidikan kesehatan PHBS belum memiliki latar belakang Pendidikan kesehatan, dan belum seluruhnya mendapatkan pelatihan PHBS untuk institusi pendidikan. Namun SDM tersebut sudah memiliki jabatan fungional dengan SOTK dan Surat Tugas/ Surat Keputusan Penugasan oleh Kepala Puskesmas.

Pembiayaan kegiatan Pendidikan kesehatan PHBS sudah tersedia. Sedangkan sarana prasarana yang dibutuhkan masih belum mencukupi karena beberapa alat dalam kondisi rusak. Metode untuk pelaksanaan kegiatan sudah mengacu pada Permenkes No: 2269/menkes/per/XI/2011 walaupun belum tersedia petunjuk pelaksanaan dan petunjuk teknis khusus PHBS institusi Pendidikan.

Pelaksanaan kegiatan pendidikan kesehatan PHBS institusi pendidikan disesuaikan dengan permasalahan yang didapatkan setelah petugas melakukan observasi dan identifikasi masalah pada masing-masing institusi pendidikan. Beberapa institusi melaksanakan kegiatan PHBS institusi pendidikan secara berkelanjutan dan terus melakukan inovasi dalam mengubah perilaku siswanya dengan tujuan mencapai sekolah sehat, namun masih ada sekolah yang sudah diberi penyuluhan akan tetapi tidak melaksanakan PHBS institusi pendidikan secara berkelanjutan. 


\section{DAFTAR PUSTAKA}

1. Kementerian Kesehatan Republik Indonesia. Permenkes RI Nomor : 2269/MENKES/PER/XI/2011.

Pedoman Pembinaan Perilaku Hidup Bersih dan Sehat (PHBS). Indonesia, 2011.

2. Adiwiryano RM. Pesan Kesehatan: Perilakku Hidup Bersih Sehat Anak Usia Dini Dalam Kurikulum Pendidikan Anak Usia Dini.

3. Komisi Perlindungan Anak Indonesia. Menyelamatkan Anak dari Bahaya Rokok.

4. Departemen Kesehatan Republik Indonesia. Buku Panduan : Manajemen Penyuluhan Kesehatan Masyarakat Tingkat Puskesmas. Jakarta: Departemen Kesehatan Republik Indonesia, 1997.

5. Hasibuan MSP. Manajemen Sumber Daya Manusia. Ed Revisi Jakarta Bumi Aksara. Epub ahead of print 2011.

DOI: 10.1017/CBO9781107415324.004.

6. Raharjo AS, Indarjo S. Hubungan antara Pengetahuan, Sikap, dan Ketersediaan Fasilitas di Sekolah dalam Penerapan PHBS Membuang Sampah pada Tempatnya. Unnes $J$ Public Heal 2014; 3: 1-10.

7. Lubis WN. Faktor-Faktor yang Berhubungan dengan Pelaksanaan Usaha Kesehatan Sekolah (UKS) di Tingkat Sekolah Dasar Wilayah Kerja Puskesmas Pamulang Kota Tangerang Selatan. Universitas Islam Negeri Syarif Hidayatullah, 2016. 